\title{
Decomposed Approach of Market Orientation and Marketing Mix Capability: Research on Their Relationships with Firm Performance in the Korean Context
}

\author{
Sohyoun Shin \\ College of Business and Public Administration, Eastern Washington University \\ 668 N. Riverpoint Blvd. Spokane, WA 99202, U.S.A \\ Tel: 1-509-828-1243 E-mail: sshin@ewu.edu
}

Received: June 6, 2011

doi:10.5539/ibr.v5n1p22

\author{
Accepted: October 18, 2011 \\ Published: January 1, 2012 \\ URL: http://dx.doi.org/10.5539/ibr.v5n1p22
}

\begin{abstract}
The notion that market orientation provides firms a source of competitive advantage seems to be widely accepted since the effects of market orientation on business performance have been extensively researched and many studies have confirmed their affirmative relationships. However, aggregated approach of market orientation as one single construct has left the detailed investigations yet unexplored despite its tremendous contribution in marketing strategy arena. Thus, decomposed properties of market orientation and their relationships with various components of firm success were explored to precisely examine the paths in this study. Furthermore, to resolve conflicting arguments on whether market orientation has a direct influence on firm level consequences, marketing mix capability was suggested as a critical mediator to complete a resource deployment system rather than a resource possession approach, which is equivalent to resource-based view. From an analysis of a survey data of 285 Korean organizations, three dimensions of market orientation, namely customer orientation, competitor orientation, and interfunctional coordination, and four sub-constructs of marketing mix capability, such as product, communication, channel and pricing capability, along with their impacts on business performance were investigated in detail. This study revealed that customer orientation and interfunctional coordination had a direct impact on only customer satisfaction while all three dimensions of market orientation failed to directly link to other firm performance variables like market effectiveness, adaptability, and profitability. To bridge these relationships product and communication capabilities were proven to be a necessary condition while channel capability and pricing capability showed interesting relationships. Findings and implications were discussed and limitations and further research directions were also suggested.
\end{abstract}

Keywords: Market orientation, Customer orientation, Competitor orientation, Interfunctional coordination, Marketing capability, Product capability, Communication capability, Channel capability, Pricing capability, Firm performance, Resource-based view

\section{Introduction}

\subsection{Research Background}

There have been numerous researches on conceptualization of market orientation and its relationship with business performance. The notion that market orientation provides firms a source of competitive advantage seems to be widely accepted since there are a large number of studies confirming that market orientation associates positively with various dimensions of firm performance (Aziz \& Yassin, 2010; Homburg \& Pflesser, 2000; Jaworski \& Kohli, 1993; Mahmoud, 2011; Ruekert, 1992; Slater \& Narver, 1994, 2000; Wei \& Morgan, 2004; Zhou, Le, \& Su, 2008) including a meta-analysis providing a positive, significant, and robust link (Kirca, Jayachandran, \& Bearden, 2005). However, another group of studies report no significant relationship (Deshpande, Farley, \& Webster, 1993; Diamantopoulos \& Hart, 1993; Greenley, Hooley, \& Rudd, 2005; Han, Kim, \& Srivastava, 1998; Pelham, 1997; Siguaw, Simpson, \& Baker, 1998), or find mixed results (Greenley, 1995; Jaworski \& Kohli, 1993), showing that perhaps the relationship is more complex than a directly linked linear one (Hult \& Ketchen, 2001). Thus, market orientation as a critical organizational resource for a firm level success is very plausible and persuasive yet how to deploy this important intangible asset to obtain better firm rents has not been fully explored. As a shortcoming of resource-based view approach, only possession of this essential resource may not automatically result affirmative 
business consequences. The actualization through organizational capability should provide a missing link between market orientation and business performance drawing a whole structure of resource deployment system. Furthermore, to understand the detailed natures of market orientation, a disaggregated view of market orientation; customer orientation and competitor orientation; has been started to treat each component as an important separate construct in developing a competitive advantage (Gatignon \& Xuereb, 1997; Lukas \& Ferrell, 2000). Therefore, researches on market orientation should shift its focus, moving from the study of the effect of single-dimensioned market orientation on business performance to the study of the impact of decomposed level of market orientation on firm performance and understandings of the distinctive characteristics of each dimension as a separate construct.

The objective of the study is to examine the detailed effects of the decomposed variables of market orientations; customer orientation, competitor orientation, and interfunctional coordination, on firm level performance variables through a mediator of marketing mix capability. All these three focal constructs are to be investigated at the disaggregated level to provide deeper understandings on how organizational resources like customer intimacy and close sensing on competitors' actions are engineered through marketing execution tools and ultimately transform into business performance. All the detailed relationships are to be suggested based on the specific theoretically driven paths in this study. Thus, the findings may provide new insights regarding the process by which market orientation is connected with firm performance and also indicate that market orientation requires complementary organizational capabilities if its values are to be fully realized. This study provides a new empirical support for the complete resource deployment system of market orientation-capability-performance in the Korean context.

\subsection{Research Model}

Figure 1 illustrates the research model in this study. The author proposes the relationship among three components of market orientation and four types of marketing mix capability with four dimensions of firm performance. More specifically, the author attempts to derive the layered relationships among market orientation, critical mediating factor for firm success; marketing capability, and business performance, which is firm level consequence of customer satisfaction, market effectiveness, adaptability, and profitability.

\section{Theoretical Background and Hypotheses}

A review of the literature reveals diverse definitions of the market orientation. Narver \& Slater (1990) define market orientation as "the organization culture that most effectively creates the necessary behaviors for the creation of superior value for buyers and, thus, continuous superior performance for the business" (Narver \& Slater, 1990, p. 21). By suggesting that market orientation is essentially an 'organization culture,' Narver and Slater (1990) appear to adopt a cultural perspective (Deshpande \& Webster, 1989). This culture comprises three behavioral components: customer orientation, competitor orientation and interfunctional coordination (Narver \& Slater, 1990). In other hand, Kohli \& Jaworski (1990, p. 6) define market orientation as "the organization-wide generation of market intelligence pertaining to current and future customer needs, dissemination of intelligence across departments, and organizationwide responsiveness to it." Both concepts of market orientation place the highest priority on the profitable creation and maintenance of superior customer value, so market orientation and its positive effects on business performance including new product success and profitability have been extensively studied (e.g., Grinstein, 2008; Han, Kim, \& Srivastava, 1998; Jaworski \& Kohli, 1993; Narver \& Slater, 1990; Slater \& Narver, 1994, 2000; Zhou \& Li, 2010).

However, cultural orientation or organizational climate like customer and competitor orientation doesn't seem to reach out to business performance in a direct way without any execution mechanism. Thus, this principal question concerning how each of decomposed values of market orientation transforms into firm performance and if there should be a mediator, how they collectively enable the organization to better perform through the mediator should be explored and answered. The author proposes that marketing mix capability may complete the missing bridge between market orientation and business performance since marketing capability is defined as "an organization's repeatable patterns to apply the resources of the firm to the market-related needs of the business" (Amit \& Shoemaker, 1993; Day 1994; Shin, Lee, \& Chaiy, 2009; Vorhies \& Morgan, 2005). The detailed paths among market orientation; customer orientation, competitor orientation, and interfunctional coordination; and marketing mix capability; product, communication, channel, and pricing capability; with firm performance; customer satisfaction, market effectiveness, adaptability, and profitability are to investigate in this study.

\subsection{Customer Orientation, Marketing Mix Capability and Firm Performance}

Customer orientation emphasizes the sufficient understanding of the target customers so as to deliver superior values for them. Thus, customer-oriented firms show a continuous and proactive disposition toward identifying and meeting customers' expressed and latent needs (Han, Kim, \& Srivastava, 1998). With customer-oriented values, firms excel in creating and maintaining bonds with customers and therefore obtain affirmative attitudes, linking 
customer satisfaction as well as positive financial outcomes (Zhou \& Li, 2010). However, in some cases cultural value like customer orientation is not just enough for cultivating firm performance. To deploy this strategic orientation for better firms' results, well-designed marketing functional process may be needed as a sufficient condition to enable it. Hence, marketing mix capability is expected to act as a connecting engine by carefully reforming a new solution, developing novel approaches of advertisements and sales promotions, providing a right range of the pricing scheme, and placing products at the right place and time for the customers. These carefully programmed and deployed marketing activities can transform the organizational cultural level of customer orientation to better customer satisfaction, market share growth, and profitability. From its clear concept, it is very plausible that marketing mix capability links an essential intangible asset of the firm like customer orientation to better firm performance. Especially when customer needs change in rapid, customer orientation enables firms to recognize those changes, and guides themselves to investigate necessary actions and build relevant abilities to develop appropriate programs to meet customers' needs. When the market circumstances are rather stable, each different aspects of marketing mix capability can also be continuously enhanced by sharing core values in customer-centric view. As implied, firms should be customer-oriented and equipped with marketing mix capability to effectively employ this orientation for optimal level marketing activities, which may result in firm performance. Hence, the author hypothesizes that:

H1: Customer orientation of a firm increases its business performance via marketing mix capability.

\subsection{Competitor Orientations Marketing Mix Capability and Firm Performance}

Competitor orientation focuses on understanding the strengths and weaknesses of existing and potential competitors as well as on monitoring their behaviors to convert into better ideas to meet the latent and potential needed of the customers (Narver \& Slater, 1990). With a deep understanding of rivals, a firm can assess its position, determine appropriate strategies, and respond quickly to competitors' actions by promptly altering precise actions in a short run and also by developing modified marketing programs in a long run. Grinstein (2008) has claimed that market orientation components positively affect new product process, which is also a critical part of marketing mix capability, and the effect of competitor orientation to new product success depends on a minimum level of customer orientation in his meta-analysis. In a longitudinal study of retail industry, competitor orientation is proven to have a strong impact on business performance (Nobel, Sinha, \& Kumar, 2002). Meanwhile, some other studies have failed to prove the relationship between competitor orientation and market adaptive capability, which is organizational competency of reacting properly to changes in market needs with new products or new market creation (e.g., Zhou $\& \mathrm{Li}, 2010$ ). Although the exact relationship between competitor orientation and marketing mix capability has rarely been explored, competitor orientation is still expected to facilitate firms' marketing mix capability. Firms should adapt the market dynamics caused by competitors and try to better understand the altered market needs, hence better firm performance because the objective of competitor-centered approach is to keep pace with or remain ahead of competitors (Han, Kim, \& Srivastava, 1998). In addition, competitor orientation helps firms configure or reconfigure their resources to provide advanced customer values and satisfaction by investigating competitive, differentiated, and also distinctive marketing programs. Specifically, firms' ability of competitive pricing strategy, differentiated channel management, and unique marketing communications can be better supported by high level of organizational competitor orientation. These combinations of resources and capability may result in better firm performance. Hence, the author hypothesizes that:

H2: Competitor orientation of a firm increases its business performance via marketing mix capability.

\subsection{Interfunctional Coordination, Marketing Mix Capability and Firm Performance}

The third of the three core components of market orientation is interfunctional coordination that is the coordination of personnel and other resources from throughout the company to create value for customers. Companies that seek effective interfunctional coordination do so from a understanding that all departments in a firm should be sensitized to act in the best interests of the customer and that each department is important in delivering superior customer value. Porter (1985) emphasizes that every department, facility, branch office and other organizational unit has a role that must be defined and understood and all employees, regardless of their distance from the strategy formulation process, must recognize their role in helping a firm achieve and sustain competitive advantage. There are many potential interfaces between the company and its customers hence the need to ensure all functional areas are committed to delivering superior value. As a component of market orientation interfunctional coordination has been proven to have a direct or an indirect link to various dimensions of business performance such as new products development (Grinstein, 2008; Han, Kim, \& Srivastava, 1998), profitability (Narver \& Slater, 1990), and overall business performance (Jaworski \& Kohli, 1993). However, there are relatively little studies which exclusively focus on the direct relationship between interfunctional coordination and business performance although there is a general 
notion that the overall effectiveness of the company's value proposition linking to profitability may be significantly compromised with interfunctional supports. This organizational value is expected to contribute to business performance if it is correctly guided to be used on which specific marketing activities. Therefore, interfunctional coordination may help firms generate better customer value when it is combined with execution abilities of marketing programs such as advanced new solution development process, integrative marketing communications and well supported networks design. Hence, the author hypothesizes that:

H3: Interfunctional coordination of a firm increases its business performance via marketing mix capability.

\section{Research Design}

\subsection{Sampling the Population}

Survey with a convenience sampling method was used in this study. The sample was restricted to the area of Seoul the capital of South Korea and its metropolitan coverage since more than one quarter of the total population resides. Moreover most suitable organizations as representative samples are located within this area. Using a list of Korean top 500 firms in terms of sales a contact list of marketing and relevant department managers was formulated. Also not to be idiosyncratic to any specific industry type or size of the firms, the data were also collected from various other sources. Though it was more like a random data collection, several restricted conditions were applied. No more than two participants from the same organization joined the survey and the size and the life of the organizations were also strictly controlled not to fall into too small and young businesses only. Respondents were selected based on their responsibilities concerning various marketing related functions based on their self-identified expertise in the relevant area. The detailed instructed questionnaire with the cover letter explaining the research objectives was sent to the key informants by email after the initial contact. There were total two times of follow-up calls and also emails to encourage their participation. Data collection occurred over six weeks and resulted in a sample of 298. After discarding 13 unusable questionnaires, total 285 were determined to use for analysis.

\subsection{Sample Characteristics}

Among 285 companies 107 were manufacturing and 105 were service organizations. The average firm age was over 27 years ranging from 2 to 120 years. $82.4 \%$ of all the organizations, or strategic business units, had at least more than 100 employees with the minimum of $10.61 .4 \%$ of the respondents were managers or above and $51.6 \%$ were in marketing related functions including marketing, sales and strategy. Also respondents in research and development were 50 or $17.5 \%$ and in general management were 26 or $9.1 \%$. The average working years of the participants in the current job was 6.4 years ranging from 2 to 27. Demographic information of the samples is in Table 1.

\subsection{Data Collection and Procedure}

To avoid any method bias, the procedure of data collection was carefully designed. The respondents' answers were concealed to be anonymous such that this procedure should reduce their evaluation apprehension and the tendency of being socially desirable, which are the known sources of common method effects obtained by a common rater (Podsakoff, MacKenzie, Lee \& Podsakoff, 2003). Furthermore, to detect possible problems with non-response error, the author used two methods. First, according to the test for non-response bias by Armstrong \& Overton (1977), the tests between early and late respondents; first three weeks vs. last three weeks; were checked to examine the differences regarding the characteristics across the samples. Second, the author also did a t-test comparing the means of all variables for the random sample versus all other respondents. From two tests, the author found no statistically significant differences. Hence, on an overall basis, it was concluded that the likelihood of non-response bias was minimal (Armstrong \& Overton, 1977). Following Narver \& Slater (1990), the unit of analysis in our study was the respondent's 'business unit' as it operates in its 'principal served market.'

\subsection{Measures}

All of the measures used in this study were drawn from the existing literature. After the relevant original scales were fully examined and translated into a local language, they were altered and adapted. However, adaptation and alteration levels varied depending on the scales to fit the research contexts. Market orientation was asked in total twelve items; customer orientation in four items, competitor orientation in four items, and interfunctional coordination in four items. These measures were slightly adjusted based on the original items of the previous studies by Narver \& Salter (1990) and Gatignon \& Xuereb (1997). Marketing mix capability was asked in total nineteen items; product capability in four items, communication capability in five item, channel capability in five item, and pricing capability in five item. These items were reconstructed based on the various sets of marketing capability measures in the previous studies (e.g., Vorhies \& Morgan, 2003).

For the dependent constructs total fourteen subjective measures; customer satisfaction in four items, market effectiveness in four items, adaptability in three items, and profitability in three items were adopted from the 
previous studies. The respondents' subjectively evaluated their own firm's customers' satisfaction was measured as customer satisfaction, using a synthesis of previous measures (e.g., Fornell, Johnson, Anderson, Cha, \& Bryant, 1996; Vorhies \& Morgan, 2005). It represents the effectiveness of the organization in delivering value to its customers (Day \& Wensley, 1988; Kaplan \& Norton, 1996). Market effectiveness, using a scale that tapped the degree to which the firms' market-based goals had been accomplished (e.g., Ruekert, Walker, \& Roering, 1985; Vorhies \& Morgan, 2003), was also measured as one of business performance. Adaptability was measured, that represents the ability of the firm to respond to changes in its environment (Ruekert, Walker, \& Roering, 1985) and is considered to ultimately reflect in the market success of an organization's new products and/or services (Kaplan \& Norton, 1996; Ruekert, Walker, \& Roering, 1985). Profitability, using perceptual scales related to financial performance over the past twelve months (e.g., Morgan, Clark, \& Gooner, 2002) was also asked. Profitability is that efficiency relates to the ratio between organizational outputs and the required inputs (Ruekert, Walker, \& Roering, 1985 ) and frequently viewed by some researchers as the ultimate organizational outcome (e.g., Hunt \& Morgan, 1995).

All measures used are 7-point, Likert-type scales with the anchors $1=$ strongly disagree to $7=$ strongly agree. For further information and analysis, industry of firm and the year duration the firm has operated were asked including the numbers of employees and annual dollar sales. The number of years the respondents work and their professional functions were also recorded as control variables.

\subsection{Measure Item Modification and Questionnaire Translation}

To develop the measures for marketing mix capability raw scales were created based on the relevant literature reviews and interviews with marketing experts both in academic and practical fields. The basic categorizations were accepted based on marketing mix tools and relevant studies concerning marketing capability. However, for marketing mix capability, there are some studies approaching as a single construct (e.g., Chang, 1996; O'Cass \& Weerawardena, 2010; Weerawardena, 2003), and as multiple constructs (e.g., Tsai and Shih, 2004; Morgan, Vorhies, \& Mason, 2009; Vorhies \& Morgan, 2005). Thus, the author decided to reconstruct the items based on the set developed by Vorhies \& Morgan (2005) as specific marketing capability and other sub-divisional sets of the measures from the studies by Day (1994), Moore \& Fairhurst (2003), and O'Cass \& Weerawardena (2010). Through a sophisticated scales development procedure, four areas were determined. Product capability covers more than new product development in this study. This concept pertains to new product development, current product management, and total portfolio control. The scales from promotion capability and sales capability were found to be highly correlated so they were combined as communication capability. Communication capability contains marketing promotion effectiveness including advertising and public relations, and sales promotion skills for the long-term benefits. Channel capability consists of channel management and network competency including alliance formulation. Pricing capability holds sophisticated skills on price setting and adjustment, and monitoring and responding to competitor's pricing.

In the process of translating original English measures into Korean, the author conducted several interviews with business experts and researchers in the related fields again. To enhance translation equivalence, the translation-backtranslation method was used (Douglas \& Craig, 1983). The translated questionnaires were also pre-tested by fifteen master course students with at least one-year field experience in the metropolitan area of Korea. Pretest samples were not included in the analysis sample since some of the items were amended or even dropped to better fit the context for this study.

\section{Data Analysis and Results}

\subsection{Reliability Check}

The measurement properties of the scales in this study were assessed via confirmatory factor analysis (CFA) and reliability check. In the CFA model all the constructs represents first-order factors. The measurement model showed a good fit with $\chi^{2}=1826.35$ (RMSEA $=.061$, SRMR $=.048$, CFI $=.92$, NNFI $\left.=.91\right)$. All items were loaded significantly on their designated constructs with no evidence of cross-loading. Factor and item loadings all exceeded .65, with t-values between 11.56 and 21.02. A test of reliability using Cronbach's coefficient alpha showed that all three sub-constructs of market orientation exceeded Nunnally's (1978) standard of .70 (customer orientation: .90; competitor orientation: .83; interfunctional coordination; .91). Cronbach's alpha for all of marketing mix capability also exceeded Nunnally's (1978) standard (product capability: .85; communication capability; .93; channel capability: .92; pricing capability: .92). All the dependent measures also satisfied the cut-off standard (customer satisfaction: .94; market effectiveness; .91; adaptability: .91; profitability: .92). Therefore, the author established support for convergent validity (Bagozzi \& Yi 1988) of the constructs, exhibiting good measurement properties. The summed means of all the measures were used for the hypotheses analysis. 


\subsection{Research Model Test Results}

The presented path model was assessed using multi-level regression with SPSS suite. First, all affirmative relationships between all three components of market orientation and all four marketing mix capability were supported. For customer orientation an influence of .367, .314, .127, and .214, for competitor orientation an influence of $.355, .276, .329$, and .338 , and for interfunctional coordination an influence of $.110, .199, .230$, and .125 on product, communication, channel and pricing capability in order were found. All the relationships were statistically supported. However, only product and communication capability were proven to have positive impacts on all four dimensions of firm performance; customer satisfaction, market effectiveness, adaptability, and profitability. Specifically, the impacts of product capability on each of business performance values were $.408, .377, .352$, and .399 and the impacts of communication capability were $.548, .426, .574$, and .336 in order. Meanwhile pricing capability on customer satisfaction and channel capability on profitability only showed statistically proven relationships (104 and -.144 in order). Interestingly, the relationship between channel capability and profitability showed a negative correlation, which was an opposite of the predicted direction. One more interesting result was that competitor orientation showed a negative direct link to customer satisfaction (-.120) although customer orientation and interfunctional coordination were proven to have direct positive impacts on customer satisfaction (.122 and .117 in order). The results of the analysis of all the paths in the proposed model were presented with R square (Adj. R square) and F values for each equations in Table 2 and Table 3.

\section{Discussions}

\subsection{Findings and Implications}

This study delivers several meaningful contributions. First, this study provides another evidence that market orientation links to business performance in indirect way. Without marketing mix capability none of customer orientation, competitor orientation, or interfunctional coordination has directly contributed to better firm performance except customer satisfaction. Especially, competitor orientation has been proven to have a direct negative impact on customer satisfaction in this study, and it is certain that a critical mediator like marketing capability is needed to neutralize its impact, or even turn its negative influence into positive. Through two types of marketing mix capability, which are specific organizational processes of product development and marketing communication, competitor orientation has successfully converted its critical contribution to firm rents. Second, as a critical mediator, product and communication capabilities have satisfyingly linked all three sub-constructs of market orientation with business performance. However, pricing capability has shown an affirmative relationship with only customer satisfaction while channel capability has shown a negative connection with profitability. This interesting result suggests further investigation between marketing mix capability and business performance while clearly indicates product and communication capabilities are the most critical connectors between market orientation and firm performance. Third, among control variables firm size and industry type also have presented interesting relationships with business performance. Large firms have proven to have a better capability of product and communication while manufacturing industry has shown to have a better ability on pricing strategy than service firms. It may be worthwhile to investigate more regarding the influence of control variables to deeper understand the relationship with the focal constructs. Forth, by assessing all the relationships of the focal constructs at a disaggregated level, this study has provided very detailed guidelines to the academicians and business practitioners on how to utilize organizational resources as a competitive advantage creator. The importance of learning the systematic process towards business performance started from market orientation has been proven in this study.

The author also believes that the findings provide a few implications in the context of execution of marketing strategy to marketing practitioners searching a way out from harsh competitive environments. First, to blossom an organization's business, marketing executives should accept that essential cultural value like market orientation plays an important role to obtain better business results but should not assume as a sufficient condition. Rather they should foster marketing capability including product and communication ability since these two capabilities have proven to be the most impactful factor in the study. Since only possession of cultural orientation does not automatically generate business performance, careful budget allocations on each sub-construct may bring balanced assignments and higher productivity leading to excellent performance. Therefore, marketing executives should deeply consider how to designate their limited resources to where to carpet productive processes from cultural resources, marketing mix capability, to firms' positive consequences. The author may suggest possible answers to them why the organizations with the same amount of resources differ from each other regarding their business performance.

\subsection{Limitations and Directions}

Despite insights grained through our results, there are several limitations of the study. The main limitation is this 
research was conducted with the survey responses provided by one key informant per firm or business unit. Although such an approach has long been fruitfully used in strategy research (Hult, Ketchen, and Slater, 2005), using multiple informants might be recommended for further research. Second, though the author designed the research avoiding any possible bias incidence, it may be impossible not to accept that there is still a chance. Specifically, subjective measures of organizational performance from managerial professionals were considered to be consistent with objective performance (e.g., Naman and Slevin 1993) but objective scales may be needed to consolidate the results. Further, this study did not investigate the interrelationships among sub-constructs themselves. The author did not offer a specific hypothesis, but expects that each of components will be significantly related to each other. Additional research might explore more complete research regarding other paths of strategic orientations such as learning and technology orientation, to business performance with or without a mediator. Moreover, studies on how the relationships among focal constructs differ based on various contextual contexts including environmental turbulence and competitive intensity. In other words, further research might extend our hypotheses to different research domains with more fine-tuned constructs from multi informants across more various industries.

\section{References}

Amit, Raphael, \& Paul J. H. Shoemaker. (1993). Strategic Assets and Organizational Rent. Strategic Management Journal, 14 (1), 33-46. http://dx.doi.org/10.1002/smj.4250140105

Armstrong, J. Scott, \& Terry S. Overton. (1977). Estimating Non-response Bias in Mail Surveys. Journal of Marketing Research, 14 (August), 396-402. http://dx.doi.org/10.2307/3150783

Aziz, Norzalita Abd, \& Norjaya Mohd Yassin. (2010). How Will Market Orientation and External Environment Influence the Performance among SMEs in the Agro-Food Sector in Malaysia? International Business Research, 3(3), 154-164.

Bagozzi, Richard P., \& Youjae Yi. (1988). On the Evaluation of Structural Equation Models. Journal of the Academy of Marketing Science, 16 (1), 74-94. http://dx.doi.org/10.1007/BF02723327

Chang, Tung-lung. (1996). Cultivating Global Experience Curve Advatage on Technology and Marketing Capabilities. International Marketing Review, 13 (6), 22-42.

Day, G. S., \& R. Wensley. (1988). Assessing Advantage: A Framework for Diagnosing Competitive Superiority. Journal of Marketing, 52(2), 1-20. http://dx.doi.org/10.2307/1251261

Day, G. S. (1994). The Capabilities of Market-Driven Organizations. Journal of Marketing, 58 (4), 37-52. http://dx.doi.org/10.2307/1251915

Deshpande, Rohit, John U Farley, \& Frederick E. Jr. Webster (1989). Organizational Culture and Marketing: Defining the Research Agenda. Journal of Marketing, 53(1), 3-15. http://dx.doi.org/10.2307/1251521

Deshpande, Rohit, John U Farley, \& Frederick E. Jr. Webster (1993). Corporate Culture, Customer Orientation, and Innovativeness in Japanese Firms: a Quadrad Analysis. Journal of Marketing, 57, 23-37. http://dx.doi.org/10.2307/1252055

Diamantopoulos, A., \& S. Hart (1993). Linking Market Orientation and Company Performance: Preliminary Evidence on Kohli and Jaworski's Framework. Journal of Strategic Marketing, 1, 93-121. http://dx.doi.org/10.1080/09652549300000007

Douglas, SP., \& CS Craig. (1983). International Marketing Research. Englewood Cliffs, (NJ): Prentice Hall.

Fornell, Claes, Michael D. Johnson, Eugene W. Anderson, Jae-sung Cha, \& Barbara Everett Bryant (1996). The American Customer Satisfaction Index: Nature, Purpose, and Findings. Journal of Marketing, 60, 7-18. http://dx.doi.org/10.2307/1251898

Gatignon, Hubert, \& Jean-Marc Xuereb. (1997). Strategic Orientation of the Firm and New Product Performance. Journal of Marketing Research, 34, 77-90. http://dx.doi.org/10.2307/3152066

Greenley, Gordon E. (1995). Forms of Market Orientation in UK companies. Journal of Management, 32(1), 47-66.

Greenley, Gordon E., Graham J. Hooley, \& ohn M. Rudd. (2005). Market Orientation in a Multiple Stakeholder Orientation Context: Implications for Marketing Capabilities and Assets. Journal of Business Research, 58(11), 1483-1494. http://dx.doi.org/10.1016/j.jbusres.2004.07.004

Grinstein A. (2008). The Relationships between Market Orientation and Alternative Strategic Orientations: A Meta-analysis. European Journal of Marketing, 42(1/2), 115-134. http://dx.doi.org/10.1108/03090560810840934

Han, Jin K., Kim, Namwoon, \& Srivastava, Rajendra K. (1998). Market Orientation and Organizational 
Performance: Is Innovation the Missing Link? Journal of Marketing, 62, 30-45. http://dx.doi.org/10.2307/1252285

Homburg, Christian, \& Pflesser Christian. (2000). A Multiple-Layer Model of Market-Oriented Organizational Culture: Measurement Issues and Performance Outcomes. Journal of Marketing Research, 37(4), 449-462. http://dx.doi.org/10.1509/jmkr.37.4.449.18786

Hult, G. Tomas M., \& David J. Ketchen Jr. (2001). Does Market Orientation Matter?: A Test of the Relationship between Positional Advantage and Performance. Strategic Management Journal, 22(9), 899-906. http://dx.doi.org/10.1002/smj.197

Hult, G. Tomas M., David J. Ketchen Jr, \& Stanley F. Slater. (2005). Market Orientation and Performance: An Integration of Disparate Approaches. Strategic Management Journal, 26(12), 1173-1181. http://dx.doi.org/10.1002/smj.494

Hunt, S. D., \& Morgan, R. M. (1995). The Comparative Advantage Theory of Competition. Journal of Marketing, 59, 1-15. http://dx.doi.org/10.2307/1252069

Jaworski, Bernard J., \& Ajay K. Kohli. (1993). Market Orientation: Antecedents and Consequences. Journal of Marketing, 57, 53-70. http://dx.doi.org/10.2307/1251854

Kaplan, Robert S. David, \& P. Norton (1996). Using the Balanced Scorecard as a Strategic Management System. Harvard Business Review, January-February, 75-85.

Kirca, Ahmet H, Satish Jayachandran, \& William O. Bearden. (2005). Market Orientation: A Meta-Analytic Review and Assessment of Its Antecedents and Impact on Performance. Journal of Marketing, 69(2), 24-41. http://dx.doi.org/10.1509/jmkg.69.2.24.60761

Kohli, A. K., \& B. J. Jaworski (1990). Market Orientation: the Construct, Research Propositions, and Managerial Implications. Journal of Marketing, 54 (April), 1-18. http://dx.doi.org/10.2307/1251866

Lukas, Bryan A., \& O. C. Ferrell (2000). The Effect of Market Orientation on Product Innovation. Journal of the Academy of Marketing Science, 28(2), 239-247. http://dx.doi.org/10.1177/0092070300282005

Mahmoud, Mohammed Abdulai. (2011). Market Orientation and Business Performance among SMEs in Ghana, International Business Research, 4(1), 241-251.

Moore, Marguerite, \& Ann Fairhurst. (2003). Marketing Capabilities and Firm Performance in Fashion Marketing. Journal of Fashion Marketing and Management, 7(4), 386-397. http://dx.doi.org/10.1108/13612020310496976

Morgan, Neil A., Bruce H. Clark, \& Richard A. Gooner. (2002). Marketing Productivity, Marketing Audits, and Systems for Marketing Performance Assessment: Integrating Multiple Perspectives. Journal of Business Research, 55(5), 363-375. http://dx.doi.org/10.1016/S0148-2963(00)00162-4

Morgan, Neil A., D. W. Vorhies, \& Charlotte H. Mason (2009). Market Orientation, Marketing Capabilities, and Firm Performance. Strategic Management Journal, 30(8), 909-920. http://dx.doi.org/10.1002/smj.764

Naman John L., \& Slevin Dennis P. (1993). Entrepreneurship and the Concept of Fit: A Model and Empirical Tests. Strategic Management Journal, 14(2), 137-153. http://dx.doi.org/10.1002/smj.4250140205

Narver, John C., \& Stanley F. Slater. (1990). The Effect of a Market Orientation on Business Profitability. Journal of Marketing, 54 (October), 20-35. http://dx.doi.org/10.2307/1251757

Nobel, C. H., R. K. Sinha, \& A. Kumar. (2002). Market Orientation and Alternative Strategic Orientations: A Longitudinal Assessments of Performance Implications. Journal of Marketing, 66(4), 25-39. http://dx.doi.org/10.1509/jmkg.66.4.25.18513

Nunnally, J. C. (1978). Psychometric Theory. New York: McGraw Hill.

O'Cass, Aron, \& Jay Weerawardena. (2010). The Effects of Perceived Industry Competitive Intensity and Marketing-related Capabilities: Drivers of Superior Brand Performance. Industrial Marketing Management, 39(4), 571-581. http://dx.doi.org/10.1016/j.indmarman.2009.04.002

Podsakoff, Philip M., S. B. MacKenzie, J. Lee, \& N. P. Podsakoff. (2003). Common Method Biases in Behavioral Research: A Critical Review of the Literature and Recommended Remedies. Journal of Applied Psychology, 88(5), 879-903. http://dx.doi.org/10.1037/0021-9010.88.5.879

Pelham, A. M. (1997). Market Orientation and Performance: the Moderating Effects of Product and Customer Differentiation. Journal of Business \& Industrial Marketing, 12(5), 276-296. http://dx.doi.org/10.1108/08858629710183257 
Porter, M. E. (1985). Competitive Advantage. Free Press, New York.

Ruekert, R. W. (1992). Developing a Market Orientation: An Organizational Strategy Perspective. International Journal of Research in Marketing, 9, 225-245. http://dx.doi.org/10.1016/0167-8116(92)90019-H

Ruekert R. W., Walker O. C., \& Roering K. J. (1985). The Organization of Marketing Activities: A Contingency Theory of Structure and Performance. Journal of Marketing, 49 (Winter), 13-25. http://dx.doi.org/10.2307/1251172

Sohyoun Shin, Sungho Lee, \& Seoil Chaiy. (2009). The Roles of Learning Orientation and Market Orientation in Driving Marketing Capabilities and Firm Performance. 2009 Korean Academy of Marketing Science Spring International Conference and Fashion Marketing Symposium.

Siguaw. J. A., Simpson, P. M., \& Baker, T. L. (1998). Effect of Supplier Market Orientation on Distributor Market Orientation and the Cannel Relationship: The Distributor Perspective. Journal of Marketing, 62(3), 99-111. http://dx.doi.org/10.2307/1251746

Slater, Stanley F., \& John C. Narver. (1994). Does Competitive Environment Moderate the Market OrientationPerformance Relationship? Journal of Marketing, 58(1), 46- 55. http://dx.doi.org/10.2307/1252250

Slater, Stanley F., \& John C. Narver. (2000). The Positive Effect of a Market Orientation on Business Profitability: A Balanced Replication. Journal of Business Research, 48, 69-73. http://dx.doi.org/10.1016/S0148-2963(98)00077-0

Tsai, M., \& Shih, C. (2004). The impact of Marketing Knowledge among Managers on Marketing Capabilities and Business Performance. International Journal of Management, 21(4), 524-530.

Vorhies, Douglas W., \& Neil A. Morgan. (2003). A Configuration Theory Assessment of Marketing Organization Fit with Business Strategy and Its Relationship with Marketing Performance. Journal of Marketing, 67(1), 100-115. http://dx.doi.org/10.1509/jmkg.67.1.100.18588

Vorhies, Douglas W., \& Neil A. Morgan. (2005). Benchmarking Marketing Capabilities for Sustainable Competitive Advantage. Journal of Marketing, 69(1), 80-94. http://dx.doi.org/10.1509/jmkg.69.1.80.55505

Weerawardena, Jay. (2003). The Role of Marketing Capability in Innovation-based Competitive Strategy. Journal of Strategic Marketing, 11, 15-35. http://dx.doi.org/10.1080/0965254032000096766

Wei, Yinghong, \& Neil A. Morgan. (2004). Supportiveness of Organizational Climate, Market Orientation, and New Product Performance in Chinese Firms. Journal of Product Innovation Management, 21, 375-388. http://dx.doi.org/10.1111/j.0737-6782.2004.00092.x

Zhou, Kevin Zheng, \& Caroline Bingxin Li. (2010). How Strategic Orientations Influence the Building of Dynamic Capability in Emerging Economies. Journal of Business Research, 63(3), 224-231. http://dx.doi.org/10.1016/j.jbusres.2009.03.003

Zhou, Kevin Zheng, ulie Juan Le, Nan Zhou, \& henting Su. (2008). Market Orientation, Job Satisfaction, Product Quality, and Firm Performance Evidence from China. Strategic Management Journal, 29, 985-1000. http://dx.doi.org/10.1002/smj.700 
Table 1. Demographic Characteristics of the Sample

\begin{tabular}{|l|l|l|l|}
\hline Items & Frequency & Percentage (\%) \\
\hline \multirow{5}{*}{ Function } & Marketing & 47 & 16.5 \\
\cline { 2 - 4 } & Sales & 52 & 18.2 \\
\cline { 2 - 4 } & Strategy/Business Planning & 48 & 16.8 \\
\cline { 2 - 4 } & R\&D & 50 & 17.5 \\
\cline { 2 - 4 } & General Management & 26 & 9.1 \\
\cline { 2 - 4 } & Others & 62 & 21.75 \\
\cline { 2 - 4 } & Total & 285 & 100.0 \\
\hline Title & Vice President/Director & 3 & 1.1 \\
\cline { 2 - 4 } & General Manager & 41 & 14.4 \\
\cline { 2 - 4 } & Manager/Assistant Manager & 131 & 46.0 \\
\cline { 2 - 4 } & Senior Staff & 106 & 37.2 \\
\cline { 2 - 4 } & Missing & 4 & 1.4 \\
\cline { 2 - 4 } & Total & 285 & 100.0 \\
\hline \multirow{5}{*}{ Type of Firm Business } & Manufacturing & 107 & 37.5 \\
\cline { 2 - 4 } & Service & 104 & 36.5 \\
\cline { 2 - 4 } & Others & 74 & 26.0 \\
\cline { 2 - 4 } & Total & 285 & 100.0 \\
\hline \multirow{5}{*}{ Firm Size } & Mean (Std. Deviation) & $6.36(4.89)$ \\
\hline Working Year & Mean (Std. Deviation) & $27.01(19.25)$ \\
\hline Firm Age & Mean (Std. Deviation) & $90289091(693149.54)$ \\
\hline Firm Sales & Mean (Std. Deviation) & $8052.11(22811.80)$ \\
\hline & & \multicolumn{2}{|l}{} \\
\hline \multirow{5}{*}{ (or } & & \multicolumn{2}{|l}{} \\
\hline
\end{tabular}


Table 2. Confirmatory Factor Analysis (CFA) Results

\begin{tabular}{|c|c|c|c|c|c|c|c|c|c|c|c|c|}
\hline & Measures & 1 & 2 & 3 & 4 & 5 & 6 & 7 & 8 & 9 & 10 & 11 \\
\hline \multirow[t]{4}{*}{ Customer Orientation } & $\mathrm{CO} 1$ & .88 & & & & & & & & & & \\
\hline & $\mathrm{CO} 2$ & .89 & & & & & & & & & & \\
\hline & $\mathrm{CO} 3$ & .81 & & & & & & & & & & \\
\hline & $\mathrm{CO} 4$ & .73 & & & & & & & & & & \\
\hline \multirow[t]{4}{*}{ Competitor Orientation } & PO1 & & .65 & & & & & & & & & \\
\hline & $\mathrm{PO} 2$ & & .86 & & & & & & & & & \\
\hline & $\mathrm{PO} 3$ & & .71 & & & & & & & & & \\
\hline & $\mathrm{PO} 4$ & & .75 & & & & & & & & & \\
\hline \multirow[t]{4}{*}{ Interfunctional Coordination } & ItF1 & & & .82 & & & & & & & & \\
\hline & ItF2 & & & .89 & & & & & & & & \\
\hline & ItF3 & & & .85 & & & & & & & & \\
\hline & ItF4 & & & .80 & & & & & & & & \\
\hline \multirow[t]{4}{*}{ Product Capability } & $\mathrm{PC} 1$ & & & & .83 & & & & & & & \\
\hline & $\mathrm{PC} 2$ & & & & .70 & & & & & & & \\
\hline & PC3 & & & & .75 & & & & & & & \\
\hline & $\mathrm{PC} 4$ & & & & .77 & & & & & & & \\
\hline \multirow[t]{5}{*}{ Communication Capability } & $\mathrm{CoC} 1$ & & & & & .88 & & & & & & \\
\hline & $\mathrm{CoC} 2$ & & & & & .89 & & & & & & \\
\hline & $\mathrm{CoC} 3$ & & & & & .86 & & & & & & \\
\hline & $\mathrm{CoC} 4$ & & & & & .79 & & & & & & \\
\hline & $\mathrm{CoC} 5$ & & & & & .80 & & & & & & \\
\hline \multirow[t]{5}{*}{ Channel Capability } & $\mathrm{ChC1}$ & & & & & & .77 & & & & & \\
\hline & $\mathrm{ChC2}$ & & & & & & .83 & & & & & \\
\hline & $\mathrm{ChC3}$ & & & & & & .90 & & & & & \\
\hline & $\mathrm{ChC4}$ & & & & & & .87 & & & & & \\
\hline & $\mathrm{ChC5}$ & & & & & & .79 & & & & & \\
\hline \multirow[t]{5}{*}{ Pricing Capability } & $\mathrm{PC} 1$ & & & & & & & .87 & & & & \\
\hline & $\mathrm{PC} 2$ & & & & & & & .85 & & & & \\
\hline & PC3 & & & & & & & .84 & & & & \\
\hline & $\mathrm{PC} 4$ & & & & & & & .84 & & & & \\
\hline & PC5 & & & & & & & .77 & & & & \\
\hline \multirow[t]{4}{*}{ Customer Satisfaction } & $\mathrm{CS} 1$ & & & & & & & & .92 & & & \\
\hline & $\mathrm{CS} 2$ & & & & & & & & .94 & & & \\
\hline & $\mathrm{CS} 3$ & & & & & & & & .89 & & & \\
\hline & $\mathrm{CS} 4$ & & & & & & & & .74 & & & \\
\hline \multirow[t]{4}{*}{ Market Effectiveness } & ME1 & & & & & & & & & .88 & & \\
\hline & ME2 & & & & & & & & & .95 & & \\
\hline & ME3 & & & & & & & & & .85 & & \\
\hline & ME4 & & & & & & & & & .74 & & \\
\hline \multirow[t]{3}{*}{ Adaptability } & AP1 & & & & & & & & & & .88 & \\
\hline & AP2 & & & & & & & & & & .89 & \\
\hline & AP3 & & & & & & & & & & .89 & \\
\hline \multirow[t]{3}{*}{ Profitability } & P1 & & & & & & & & & & & .90 \\
\hline & $\mathrm{P} 2$ & & & & & & & & & & & .90 \\
\hline & $\mathrm{P} 3$ & & & & & & & & & & & .89 \\
\hline \multicolumn{2}{|l|}{ Cronbach's Alpha } & .90 & .83 & .91 & .85 & .93 & .92 & .92 & .94 & .91 & .91 & .93 \\
\hline \multicolumn{2}{|l|}{ Mean } & 5.61 & 4.93 & 4.55 & 4.91 & 4.51 & 4.85 & 4.85 & 4.97 & 4.68 & 4.49 & 4.68 \\
\hline \multicolumn{2}{|l|}{ Standard deviation } & 1.16 & 1.21 & 1.12 & 1.16 & 1.31 & 1.11 & 1.85 & 1.24 & 1.24 & 1.34 & 1.38 \\
\hline
\end{tabular}


Table 3. Regression Test Results for Marketing Mix Capability

\begin{tabular}{|c|c|c|c|c|}
\hline & Product Capability & $\begin{array}{c}\text { Communication } \\
\text { Capability }\end{array}$ & Channel Capability & Pricing Capability \\
\hline \multicolumn{5}{|l|}{ Control Variables } \\
\hline Ln Firm Age & $-.002(\mathrm{~ns})$ & $-.070(\mathrm{~ns})$ & $.021(\mathrm{~ns})$ & $-.048(\mathrm{~ns})$ \\
\hline Ln Firm Size & $.025(\mathrm{~ns})$ & $.154 * *$ & $.082(\mathrm{~ns})$ & $.120 * *$ \\
\hline Manufacturing & $.013(\mathrm{~ns})$ & $.075(\mathrm{~ns})$ & $-.036(\mathrm{~ns})$ & $.127 * *$ \\
\hline Service & $-.051(\mathrm{~ns})$ & $-.009(\mathrm{~ns})$ & $-.020(\mathrm{~ns})$ & $-.018(\mathrm{~ns})$ \\
\hline \multicolumn{5}{|l|}{ Independent Variables } \\
\hline Customer Orientation & $.367 * * *$ & $.314 * * *$ & $.127 * * *$ & $.214 * * *$ \\
\hline Competitor Orientation & $.355^{* * *}$ & $.276^{* * *}$ & $.329 * * *$ & $.338 * * *$ \\
\hline Interfunctional Coordination & $.110^{* *}$ & $.199 * * *$ & $.230 * * *$ & $.125 * *$ \\
\hline R square (Adj. R square) & $.482(.469)$ & $.477(.463)$ & $.356(.339)$ & $.374(.359)$ \\
\hline $\mathrm{F}$ & 36.892 & 36.023 & 21.827 & 23.678 \\
\hline Sig. & .000 & .000 & .000 & .000 \\
\hline
\end{tabular}

$* * * \mathrm{p}=<.01, * * \mathrm{p}=<.05, * \mathrm{p}=<.10, \mathrm{~ns}=$ not significant

Table 4. Regression Test Results for Firm Performance

\begin{tabular}{|c|c|c|c|c|}
\hline & Customer Satisfaction & Market Effectiveness & Adaptability & Profitability \\
\hline \multicolumn{5}{|l|}{ Control Variables } \\
\hline Ln Firm Age & $.042(\mathrm{~ns})$ & $.004(\mathrm{~ns})$ & $-.015(\mathrm{~ns})$ & $.053(\mathrm{~ns})$ \\
\hline Ln Firm Size & $-.048(\mathrm{~ns})$ & $-.083(\mathrm{~ns})$ & $.015(\mathrm{~ns})$ & $.019(\mathrm{~ns})$ \\
\hline Manufacturing & $-.032(\mathrm{~ns})$ & $-.058(\mathrm{~ns})$ & $.023(\mathrm{~ns})$ & $-.068(\mathrm{~ns})$ \\
\hline Service & $.097 *$ & $.067(\mathrm{~ns})$ & $.077(\mathrm{~ns})$ & $.003(\mathrm{~ns})$ \\
\hline \multicolumn{5}{|l|}{ Independent Variables } \\
\hline Customer Orientation & $.122 * *$ & $-.058(\mathrm{~ns})$ & $-.046(\mathrm{~ns})$ & $-.102(\mathrm{~ns})$ \\
\hline Competitor Orientation & $-.120 * *$ & $-.056(\mathrm{~ns})$ & $.075(\mathrm{~ns})$ & $.105(\mathrm{~ns})$ \\
\hline Interfunctional Coordination & $.117 * *$ & $.090(\mathrm{~ns})$ & $.009(\mathrm{~ns})$ & $.053(\mathrm{~ns})$ \\
\hline Product Capability & $.287 * * *$ & $.329 * * *$ & $.442 * * *$ & $.226 * *$ \\
\hline Communication Capability & $.408 * * *$ & $.377 * * *$ & $.352 * * *$ & $.399 * * *$ \\
\hline Channel Capability & $-.094(\mathrm{~ns})$ & $-.032(\mathrm{~ns})$ & $-.078(\mathrm{~ns})$ & $-.144 * *$ \\
\hline Pricing Capability & $.104 *$ & $.068(\mathrm{~ns})$ & $.053(\mathrm{~ns})$ & $.005(\mathrm{~ns})$ \\
\hline R square (Adj. R square) & $.548(.530)$ & $.426(.402)$ & $.574(.557)$ & $.336(.309)$ \\
\hline $\mathrm{F}$ & 30.149 & 18.387 & 33.483 & 12.565 \\
\hline Sig. & .000 & .000 & .000 & .000 \\
\hline
\end{tabular}

$* * * \mathrm{p}=<.01,{ }^{* *} \mathrm{p}=<.05, * \mathrm{p}=<.10, \mathrm{~ns}=$ not significant

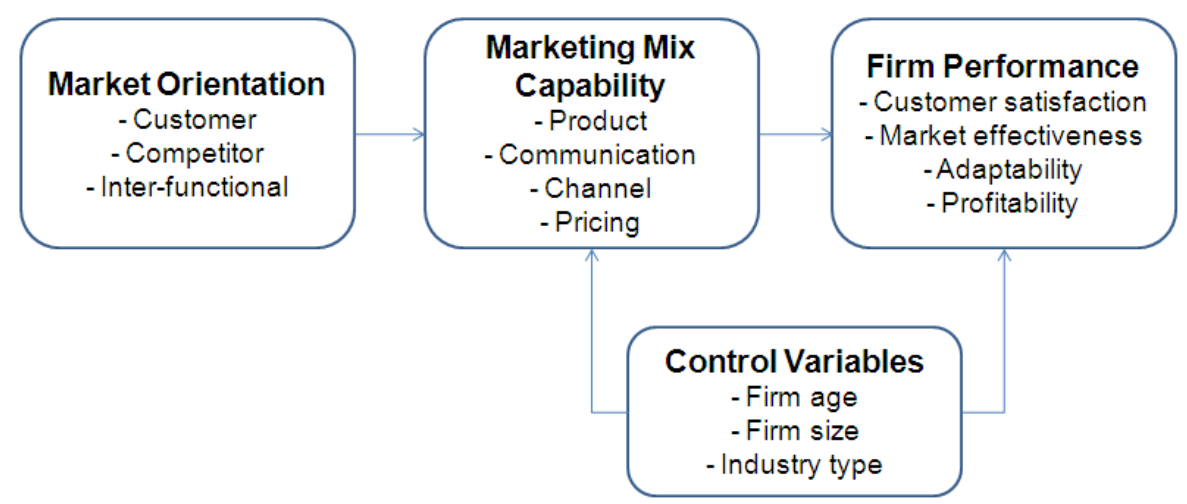

Figure 1. Research Model 